\title{
PIONEER
}

VOLUME 12, Issue 2, December 2020: 173 - 191

\section{DESCRIPTION OF THE AMERICAN COMMUNITY OF JOHN STEINBECK'S ADVENTURE IN NOVEL TRAVELS WITH CHARLEY IN SEARCH OF AMERICA 1960s}

\author{
Abbas \\ University of Hasanuddin Makassar \\ abbas@unhas.ac.id
}

\begin{abstract}
This article aims at describing the social life of the American people in several places that made the adventures of John Steinbeck as the author of the novel Travels with Charley in Search of America around the 1960s. American people's lives are a part of world civilizations that literary readers need to know. This adventure was preceded by an author's trip in New York City, then to California, Connecticut, Rhode Island, New Hampshire, Massachusetts, Maine, New Jersey, Saint Lawrence, Quebec, Niagara Falls, Ohio, Chicago, Illinois, Michigan, North Dakota, the Rocky Mountains, Washington, the West Coast, Oregon, Arizona, New Mexico, Texas, New Orleans, Salinas, and again ended in New York. In processing research data, the writer uses one of the methods of literary research, namely the Dynamic Structural Approach which emphasizes the study of the intrinsic elements of literary work and the involvement of the author in his work. The intrinsic elements emphasized in this study are the physical and social settings. The research data were obtained from the results of a literature study which were then explained descriptively. The writer found a number of descriptions of the social life of the American people in the 1960s, namely the life of the city, the situation of the inland people, and ethnic discrimination. The people of the city are busy taking care of their profession and competing for careers, inland people living naturally without competing ambitions, and black African Americans have not enjoyed the progress achieved by the Americans. The description of American society related to the fictional story is divided by region, namely east, north, middle, west, and south. The social condition in the eastern region is dominated by beaches and mountains, and is engaged in business, commerce, industry, and agriculture. The comfortable landscape in the northern region spends the people time as breeders and farmers. The natural condition in the middle region of American is very suitable for agriculture, plantations, and animal husbandry. Many people in the western American region facing the Pacific Ocean become fishermen. The natural conditions from the plains and valleys to the hills make the southern region suitable for plantation land.
\end{abstract}

Keywords: American community, adventure, novel "Travels with Charley in Search of America"

\section{INTRODUCTION}

Literary works have an inner and outward strength in influencing readers to assess the social conditions of certain societies. History is able to show social facts, but not necessarily able to lead people to the inner closeness with the atmosphere in a historic event. It is different from literary works that are able to awaken the soul 
sensitivity of readers so that they feel hypnotized as if they were witnessing firsthand the condition of the community or like feeling events in the story. A literary reader can laugh, happy, angry, upset, and even hate fictional characters because of their displeasure with the behavior of the fictional characters as proof of the existence of the soul's sensitivity.

John Steinbeck described his adventures in his fiction, entitled Travels with Charley in Search of America, as an author's social fact in showing the reality of his country to literary readers. He began his adventure in New York City, then headed to California, Connecticut, Rhode Island, New Hampshire, Massachusetts, Maine, New Jersey, Saint Lawrence, Quebec, Niagara Falls, Ohio, Chicago, Illinois, Michigan, North Dakota, the Rocky Mountains, Washington, West Coast, Oregon, Arizona, New Mexico, Texas, New Orleans, Salinas, and again ended in New York. He takes the reader to the imagination of the physical conditions and social situations of the areas refer to his visit. The American diversity of geographical and society are clearly depicted from various aspects of life, including culture, beliefs, race, ethnicity, profession, progress, and suffering. Steinbeck portrayed the state of his country, America around the 1960s which entered an era of controversy, both at home and abroad.

Olson (1992, p. 165-171) explains that in the early 1960s, America entered a new spirit under the leadership of the youngest president named John F. Kennedy. He faced the domestic problems were overcoming the gap between prosperity and unemployment, education disparity, limited access to black Americans, and Indian land claims. As one of the world's major powers, America is also threatened by the nuclear power of the Soviet Union and its allies, border conflicts with neighboring countries in the South, the economic impact of the internal conflicts of several countries in the African Continent and the Middle East Region, the threat of socialist ideology in several Asian regions and Eastern Europe.

The fact that America is a nation of various peoples on earth with various social, cultural, racial, ethnics, languages, skin colors, religious, ideas, and ideological backgrounds, is an indisputable reality. In addition, America, as the great winner of World War II, has a broad influence in the struggle for ideology, economic competition, and global military strife is also a fact. Then amidst such conditions and situations, 
Steinbeck as an author portrays the internal condition of his country through his adventures in several places as social fact in fiction. Based on this fact of imagination, the writer in this scientific article is interested in describing the social life of American society in all regions that were made as John Steinbeck's adventure area as the author of the novel Travels with Charley in Search of America around the 1960s by using Dynamic Structural Approach.

Previous literary research using Dynamic Structural Approach was conducted by Mas'ud (2013) who analyzed the education of character building in the novel The Old Man and the Sea by Ernest Miller Hemingway. An old man named Santiago is identified as an old man who provides character education to a young character named Manolin through moral messages. The dynamism of the novel The Old Man and the Sea in this study emphasizes Hemingway's semiotic communication as the author to the young character, Manolin through the old character, Santiago.

The writer of this article involves John Steinbeck as the author of the novel Travels with Charley in Search of America in exploring the geographical condition and sociological situation of America as Mas'ud in her literary research who involved Ernest Miller Hemingway as the author of the novel The Old Man and the Sea in analyzing character building education. However, there are differences in authors' involvement in the research dynamics of these two literary works. Mas'ud involves the author in the form of semiotic communications through his philosophical views, while the author in this article is involved reflectively through his life experiences. It shows that in the Dynamic Structural Approach, authors can be presented in various forms and models of involvement.

\section{REVIEW OF LITERATURE}

There are many reasons for a person to express his ideas and views on society, especially criticism related to injustice and inequality of social classes. One of the media commonly used in social criticism that is able to influence readers is literary work. A literary author with his social sensitivity is able to feel a reality in a community, ethnicity, and nation. The social reality that is understood then poured in an imaginative story is expected to be able to influence or herd the opinion of the readers. The author absorbs social reality through three spaces, namely personal life experience, 
observation of events, receipt of oral information from other people or written sources. It indicates that the author's existence in literary imagination can be considered as a reflection of the author's knowledge of the social conditions that occur around him. It is also confirmed by Faruk's statement (2014, p. 43-44) that literature as fiction is not fact, but literature as the author's imaginative work certainly has a social context that connects a number of fictional and factual events.

A number of research results linking the author's life experience with his literary works include Prospects for the Study of John Steinbeck by DeMOTT, Robert \& Brian Railsback (2007), Racism in Twain's The Adventures of Huckleberry Finn by Alwi (2019), and The Reality of American Nation Slavery in the Novel Incidents in the Life of a Slave Girl by Harriet Ann Jacobs by Abbas (2020). The relevance of this article to the three studies is the author's involvement in his literary works so that an author is not a sleeper who dreams, but he is a person who acts and thinks while imagining. The author's involvement in a fictional story is the dynamic of this literary work as John Steinbeck's involvement with the character of the story named Mac or $I$ in the novel Travels with Charley in Search of America, Mark Twain for the fictional character Huck in the novel The Adventures of Huckleberry, and Harriet Ann Jacobs with the fictional character Harriet Jacobs or Linda in the novel Incidents in the Life of a Slave Girl.

John Steinbeck according to DeMOTT et al. (2007) in his article entitled Prospects for the Study of John Steinbeck describes a controversial figure with his views on his sentiments towards the social realities of the post-depression era of American society. Steinbeck with a number of life experiences, he witnessed in various regions of America, is considered a figure who partially documents social facts. His controversial views and sentimentality in voicing social criticism through literature were one of the considerations in the awarding of the Nobel Prize for Literature that John Steinbeck received in 1962.

Alwi (2019) in his undergraduate thesis explained that there is a correlation between Mark Twain as the author and the narrator named Huck who is a character who helped the liberation of American black slaves in his novel The Adventures of Huckleberry Finn. Alwi discovered the fact that this novel kept traces of Mark Twain's social life as a young man who witnessed the practice of slavery taking place in America in the early nineteenth century. He described his experience in the form of 
adventures in America, especially southern regions such as Mississippi. The practice of slavery in this area was still legalized which white people employed black Negroes as slaves in plantation, industry, and home.

Abbas (2020) in his article found literary imaginative facts that Harriet Ann Jacobs in her novel entitled Incidents in the Life of a Slave Girl has a similarity to the story of the main character's life named Harriet Jacobs or her nickname as Linda. She is a black American slave who aspires to freedom to gain education and skills. Linda experiences suffering and travels thousands of kilometers from South to North to fight for her dream. She kept moving from one house to another, from one city to another to save herself. Linda continued to run North in Philadelphia, Brooklyn, New York, Boston to Manhattan. Linda's escape lasted for decades until she met her daughter, Ellen in New York and gathered with her son, Benny in Boston.

Then the issue of literary research that is the focus of this article is the adventure of a fictional character named Mac or I in the novel Travels with Charley in Search of America by John Steinbeck in uncovering American social reality. It is in line with the opinion of Rakshna (2016) about adventure that one's experience in making a risky journey is to prove what people think. Such activities become full of excitement and courage which are generally online and risky in nature. There are many people whom life becomes full of adventurous experiences. So, adventure is not just a tour, but an exploratory journey undertaken by a fictional character like Mac. This adventure has a symbolic meaning as well as Edy, Ariska, Hasyim \& Astuti (2020) in their research revealed the symbolic meaning of the Japanese for the fictional character Hikaru Genji in the folklore story of Genji Monogatari. He is a hero character who reflects the prince of the Japanese Empire who is adored by many women for his good looks, kindness, and courage.

\section{METHOD}

Literary works are the result of the author's imagination documented in the form of fiction. Imagination is not just a hollow story, but has hidden social facts. For example, John Steinbeck is an American realist literary author who has a lot of experience exploring American territories. He then reconstructed the experience into a fictional story that caught the reader's attention in knowing America as a nation. It 
shows that the author of literature has a relationship with his work so that a literary reviewer needs to know the position of the author in the imaginary world of literature. It becomes the basis of the study of literature that the structure of literature does not stand alone, but it also involves the author as the dynamics of literary meaning. Goring, et al. (2001, p. 163-165) informs that structuralism progressed in the 1950s and 1960s by opening space for readers to involve the author's experience in his work and this is said to be part of modern structuralism in the study of literature.

Dynamic structuralism as an approach in the study of literature opens the space for literary readers or reviewers to explore the life of the author. The author's involvement is built from the thought that literary works are made by someone in a conscious state of social spaces, he is not a person dreaming in a sleep state, but he is a conscious person who imagines. Literary structure is the world of imagination that is realized by the author of the results of its absorption in the surrounding social environment according to Endraswara (2013, p. 62) says that Dynamic Structural Approach in the literary studies always emphasizes literary works as objects of analysis which are then supported by the involvement of the author through the awareness of his subjectivity. The author's awareness is influenced by the history and social environment around him.

Literary reviewers remain focused on the structure of literary works in conducting analysis, then the authors are involved to complete the fictional facts in literary stories. Ratna (2015, p. 93-95) explains that dynamic structuralism still emphasizes the existence of literature on its intrinsic elements and opens a space of meaningful relationships between the author as the creator of the imagination and the reader as the recipient of fiction. The purpose of the reader who wants to find certain facts in the world of fiction can involve the author's background in the world of imagination. Based on this explanation, the writer of this article conducted a number of stages of research in describing American society in the novel Travels with Charley in Search of America by John Steinbeck, namely: 1) Reading several times of the novel Travels with Charley in Search of America to understand the fiction; 2) Identifying the social and physical settings of the fiction of Travels with Charley in Search of America; 3) Tracing the journey of life and experience Steinbeck as the author in getting to know the American community and territory; 4) Observing the map of the American territory 
to ensure the existence of the area described in the fiction; 5) Describing the condition of society in the American region as an imaginary fact of Steinbeck's literature in the novel Travels with Charley in Search of America around the 1960s.

\section{FINDINGS AND DISCUSSION}

\section{Findings}

The novel Travels with Charley in Search of America, written by John Steinbeck and first published in 1962 in New York by the Viking Press, consists of four parts. All parts of the story describe various corners of American territory and society, from New York City to New Orleans and back to New York. This fiction story reviews the views and thoughts of the author about the distinctiveness of ethnicity and diversity of America as a country that gathers nations from various regions of the world in an effort to build equality and justice as Steinbeck (1986, p. 210) describes it as follows:

If I found matters to criticize and to deplore, they were tendencies equally present in myself... For all of our enormous geographic range, for all of our sectionalism, for all of our interwoven breeds drawn from every part of the ethnic world, we are a nation, a new breed. Americans are much more America than they are Northerners, Southerners, Westerners, or Easterners.

The writer begins the finding of this article about the description of the novel Travels with Charley in Search of America and the social background of John Steinbeck's life as the author. Furthermore, the writer conveys the result of the analysis as the discussion of this article in the form of people descriptions in various regions of America around the 1960s who had been visited by the author in the novel.

\section{Description of the author's adventure in the novel travels with charley in search of america}

A fictional character who goes on an adventure called $I$ who is called Mac at the end of the story. The character $I$ can interpret as John Steinbeck who disguised in the story called as Mac. He did an adventure with a beloved male dog named Charley by driving a truck named Rocinante. This adventure lasts for years in various seasons, namely Summer, Rain, Autum, and Spring. The main purpose of Mac's adventure is to find the territories that became the nation's identity, namely America. He found a French identity in Paris, a British identity in London, but America cannot be described by the metropolitan city of New York. Curiosity to find the description of America in 
the American people pushed him to trace his homeland from the East to North and from North to Middle and from Middle to West and from West to South and return to the East.

Mac began his journey in New York City, which he said was a mertopolitan city, a mysterious place to find the identity of Americans. He and Charley drove Rocinante to Shelter Island Ferry, then to Greenport to Orient Point, then to the coast of Connecticut and across Long Island Sound. Along the way, he witnessed a community of French and Italian immigrants and native Indians. The next route is to the north in the Vermont region turning East in the New Hampshire region through the White Mountains mountain range. This mountainous region stretching as far as Florida, he witnessed the lives of farmers, Yankees, and Indian nobles. Next, he entered the Wisconsin area, North Dakota, Motana. This North American region stretches to the Maine region in the East. He witnessed the diversity of customs, traditions, behavior, and social structures of society.

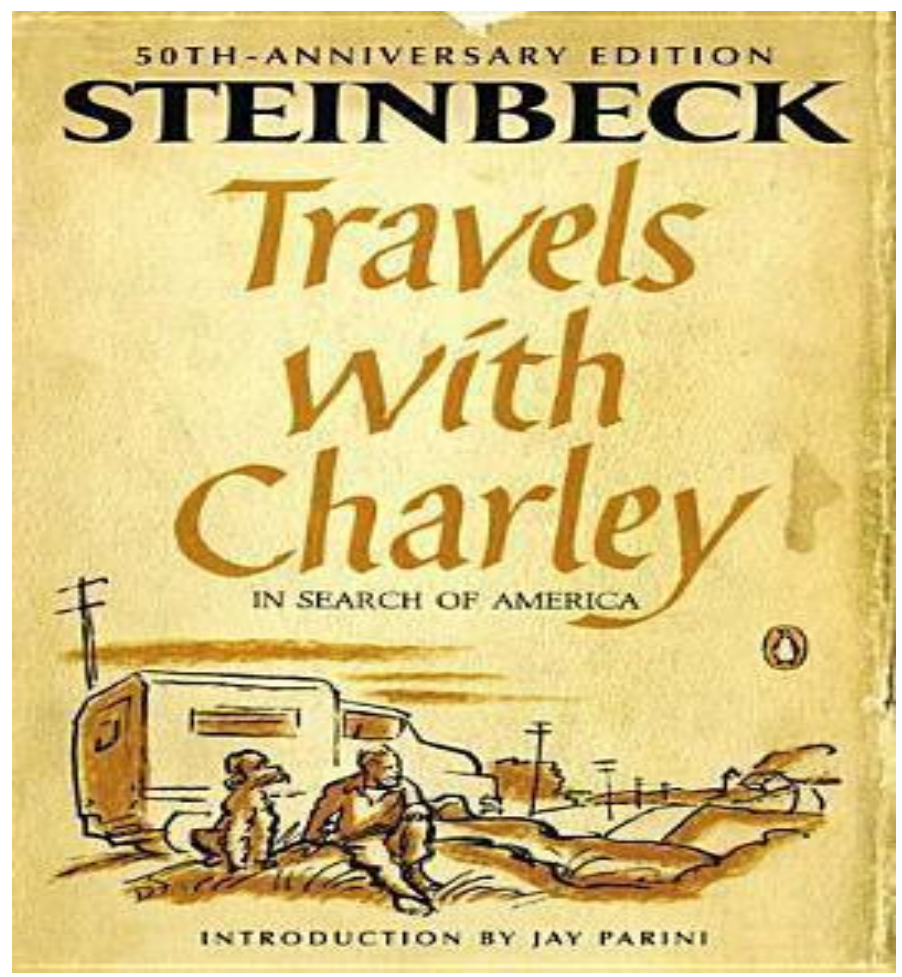

Picture 1. Cover Novel Travel with Charley in Search of America by John Steinbeck, published in New York by Penguin Book in $1986, \mathbf{5 0}^{\text {th }}$ edition

After several days in Maine along the reef coast through Millbridge, Addison, Machias, Perry, and South Robinson, Mac and Charley continued their journey north to 
Houlton, Mars Hill, Millinocket until they arrived in the city of Vermont. Along the way, he observed the new structure of American society consisting of French people, Filipinos, Indians, Mexicans, Canadians, Negroes, and others. The adventure continues through Rouses Point, Lake Ontario to Niagara Falls. He enjoyed the natural beauty of Niagara Falls, "Niagara Falls is very nice. It's like a large version of the old Bond sign on Times Square" (Steinbeck,1986, p. 84). He then entered the Ontario, Cleveland, and Toledo regions until he arrived in Michigan. He witnessed a peaceful and peaceful family setting while singing ethnic songs.

Mac adventure continues to enter the Middle West region, namely Michigan, Ohio, Indiana, Illinois, Iowa to Colorado, witnessing a significant population growth from various national backgrounds such as Norway, Irandia, Germany, France, China, Russia, and others. Next trip from Indiana to Chicago and celebrate Thanksgiving in Wisconsin. Mac continued to drive Rocinante across the eastern side of the Mississippi, across Moorhead, Minnesota, Red River to Fargo. He saw a valley area filled with cattle ranching and multi-ethnic people. The journey again took the road to North Dakota and Montana, witnessing American civilization in Yellowstone National Park.

Mac continued adventuring in the Rocky Mountains until he arrived at the Great Divide, where he watched Negroes who were successful in doing business with the French. He traveled the region from Washington to the West Coast to Seattle with a very rapid population growth. He continued to visit several regions until he arrived in Oregon just during the rainy season, "That happened on Sunday in Oregon in the rain" (Steinbeck, 1986, p. 187). He entered the Long Island region watching giant trees of having hundreds years old. Next, he headed to Northern California, San Francisco, to see the beautiful, clean, and comfortable beaches on the Monterey Peninsula, "It is a beautiful place, clean, well run, and progressive” (Steinbeck, 1986, p. 205).

The journey to find America continues through the Colorado River to Arizona, New Mexico, and Texas. He found people with hard characters, complex and mysterious personalities, hostile but united, they changed the world with terror and friendship. He stayed a long time watching people's lives in southern America, "While I was still in Texas, late in 1960, the incident most reported and pictured in the newspapers..." (Steinbeck, 1986, p. 249). He then moved toward Louisiana through Lake Charles to Florida and arrived in New Orleans and stayed at Manhattam. In this 
place, he witnessed Puritan people who were friendly and helpful. From New Orleans, Mac with Charley while driving Rocinante returned to his home in New York. People were shocked when he returned because he had long disappeared from his house, “... I've driven this thing all over the country-mountains, plains, deserts. And now I'm back in my own town, where I live-and I'm lost”' (Steinbeck, 1986, p. 277).

After visiting various regions of America, the fictional character I or Mac discovered facts about the real America, "I went out to find the truth about my country and I found it" (Steinbeck, 1986, p. 209). He concluded that the identity of the American nation is a country of various nations in the world. The diversity of ethnic backgrounds, races, religions, cultures, languages, and other aspects of social life, that is actually the American nation. They come from different backgrounds, but their souls are one in America. American democracy grows from this diversity and unity in difference can only be maintained by prosperity and justice. To know the identity of America must go through knowledge of America from all corners of the region. America cannot be concluded by just one region. America's geographical situation stretching from valleys to mountains, from rivers to lakes, and from sea to oceans, is an extraordinary natural wealth with amazing views.

\section{Social background of John Steinbeck}

John Steinbeck is a descendant of European immigrants blooded in Germany and Northern Ireland. He inherited the name from his father's family, namely his grandfather named John and his grandmother named Grossteinbeck, they were German immigrants who were Protestants who came to the South American region around the mid-nineteenth century. John Steinbeck's mother, Olive Hemilton, was a descendant of the Hemilton family from Northern Ireland who immigrated to mainland America in the mid-1850s.

Since he was born in Salinas in 1902 until he died in Salinas in 1968, John Steinbeck was loyal and loved his country, America. In all his works, both fiction and non-fiction, he does criticism and description of America as a form of love for his country. Throughout his life, he worked in various professions ranging from being a worker to a journalist, and visited various regions in America ranging from Salinas to Alaska, also visited several countries in Europe as well as visiting his ancestral territories there. 


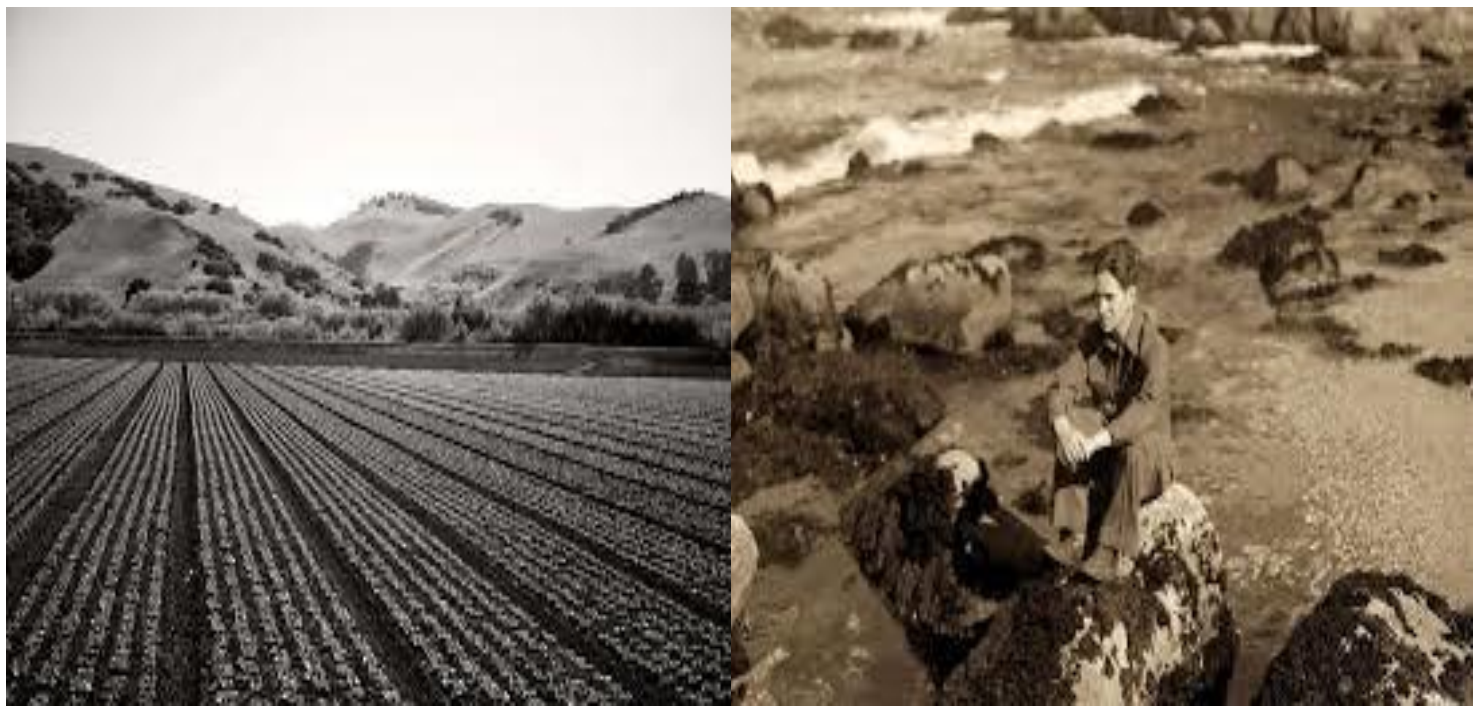

Picture 2. Adventure picture of John Steinbeck in his homeland Salinas, California 1940s

Source: https://www.google.com/search?q=adventure+picture+of+john+steinbeck\&oq accessed on December 26, 2020 at 08.55 a.m.

John Steinbeck completed his novel Travels with Charley in Search of America in 1962 when he was almost sixty years old. He has had many adventurous experiences witnessing social reality in American society documented in his fictional works. This fact is the reason for placing him as one of the realist authors as Hart's statement, "Steinbeck's fiction combines realism and romance, but not always harmoniously. His setting is rural areas, where people live most happily when close to nature..." (1986, p. 383). Reality and memories are difficult to put together in the real world because they can only be harmony in the imaginary world of literary works. The romantic soul shows that he likes to remember his life's journey in the past and documents it in his literary works.

The combination of reality and memories in John Steinbeck makes the writer believe in this article that the novel Travels with Charley in Search of America is a documentary of Steinbeck's adventures for years in witnessing American social reality. Pearson (1994, p. 306-308) described the panic of native Indians witnessing the arrival of frontiers who immigrated to the American West and this incident was witnessed by John Steinbeck. In this novel, he found his imaginary convention about America full of diversity. Even though they come from different backgrounds and diverse social realities, their souls are one for America. John Steinbeck was a nationalist literary man who was critical and sensitive to his country, America. 


\section{Discussion}

The writer in this article does not mention all the regions visited by John Steinbeck in the novel Travels with Charley in Search of America, but the description of American society is divided by region, namely East, North, Middle, West, and South. Based on the descriptions of the author's adventure regions in a novel referred to the map, so the Eastern region includes New York, Vermont, New Hampshire, Maine, Massachusetts, Rhode Island, Connecticut, New Jersey, Delaware, Maryland, and Ohio. The Northern region is Michigan, Minnesota, North Dakota, and Montana. The Middle regions includes Indiana, Illinois, Missouri, Kansas, Colorado, and Wyoming. The Western region includes Washington, Oregon, California, and Nevada. The Southern region is Arizona, New Mexico, Texas, Louisiana, Mississippi, Alabama, Florida, Georgia, and Carolina. The location of all regions in the novel described as a territory refers to a map of the United States accessed from www.suneducationgroup.com.

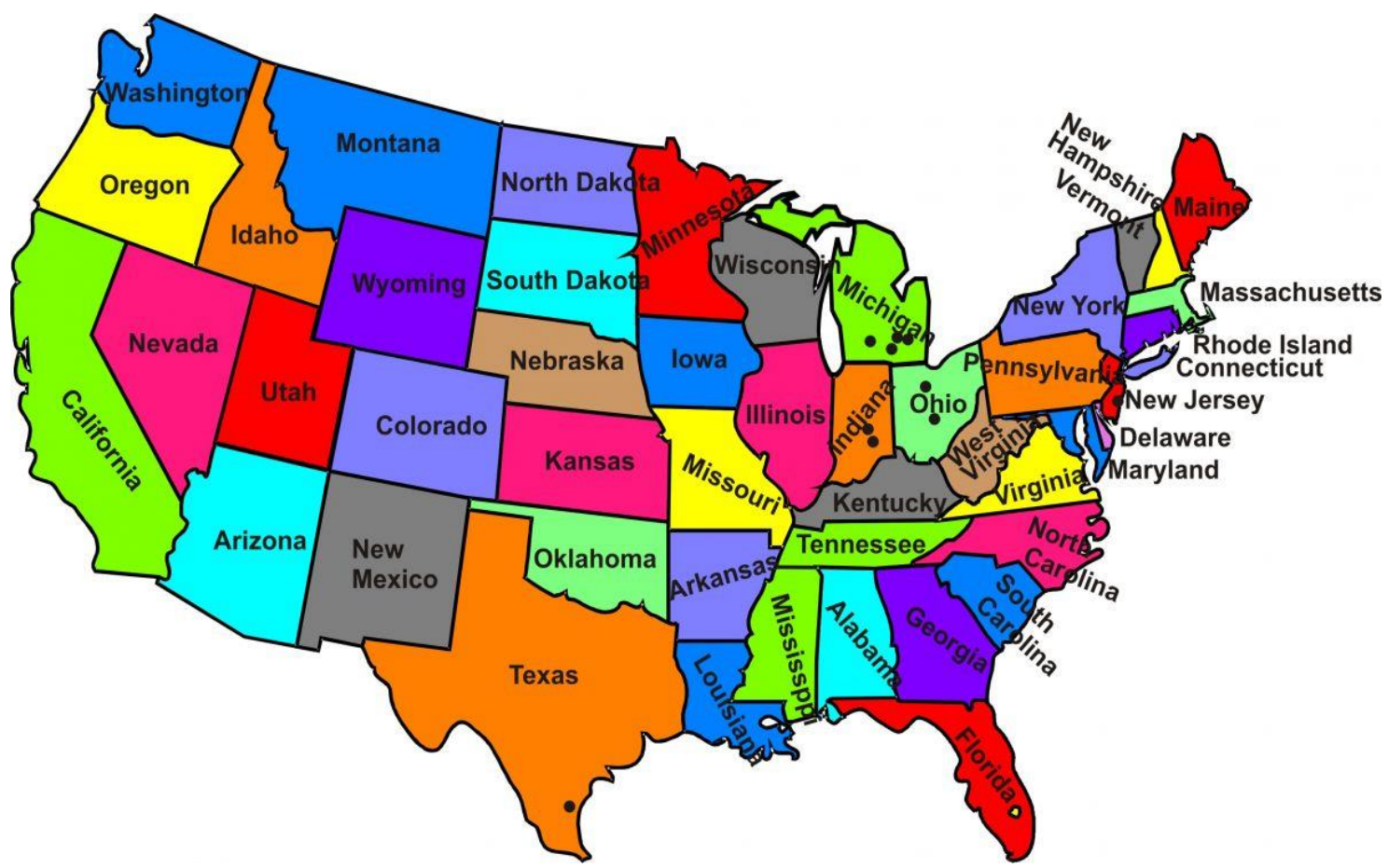

Picture 3. The Map of Geographical America from South (Texas) to North (North Dakota) and from East (North Carolina) to West (California)

Source: https://www.suneducationgroup.com, accessed on October 21, 2019 at 7.15 p.m. 


\section{Eastern region of United States}

Natural conditions in the Eastern region are dominated by beaches and mountains facing directly the Atlantic Ocean, which has weather that sometimes changes rapidly. The dominant society is engaged in business, commerce, industry, and agriculture. High life competition and individualism also mysterious soul are a description of the character of this community. Roads in big cities are filled with congestion due to crowded vehicles. Their social conditions are typical of modern societies that are busy, individualistic, and capitalist at heart. Each individual takes care of himself, interests, and life goals. The main controllers to America's economic, government, defence and vital sectors are in this region.

The Eastern region which has a regional history as a New England colony is dominated by British followers of the Protestant group. They built a spirit of AngloAmerican solidarity which called itself the Yankee community. They are commonly named this area as New London. Besides them, there are also other dominant national communities which are the French, Italians, Dutch, Jews, and Indian aristocrats as the indigenous community. They tried to do acculturation, but it was less successful and could even be said to be acculturation without form.

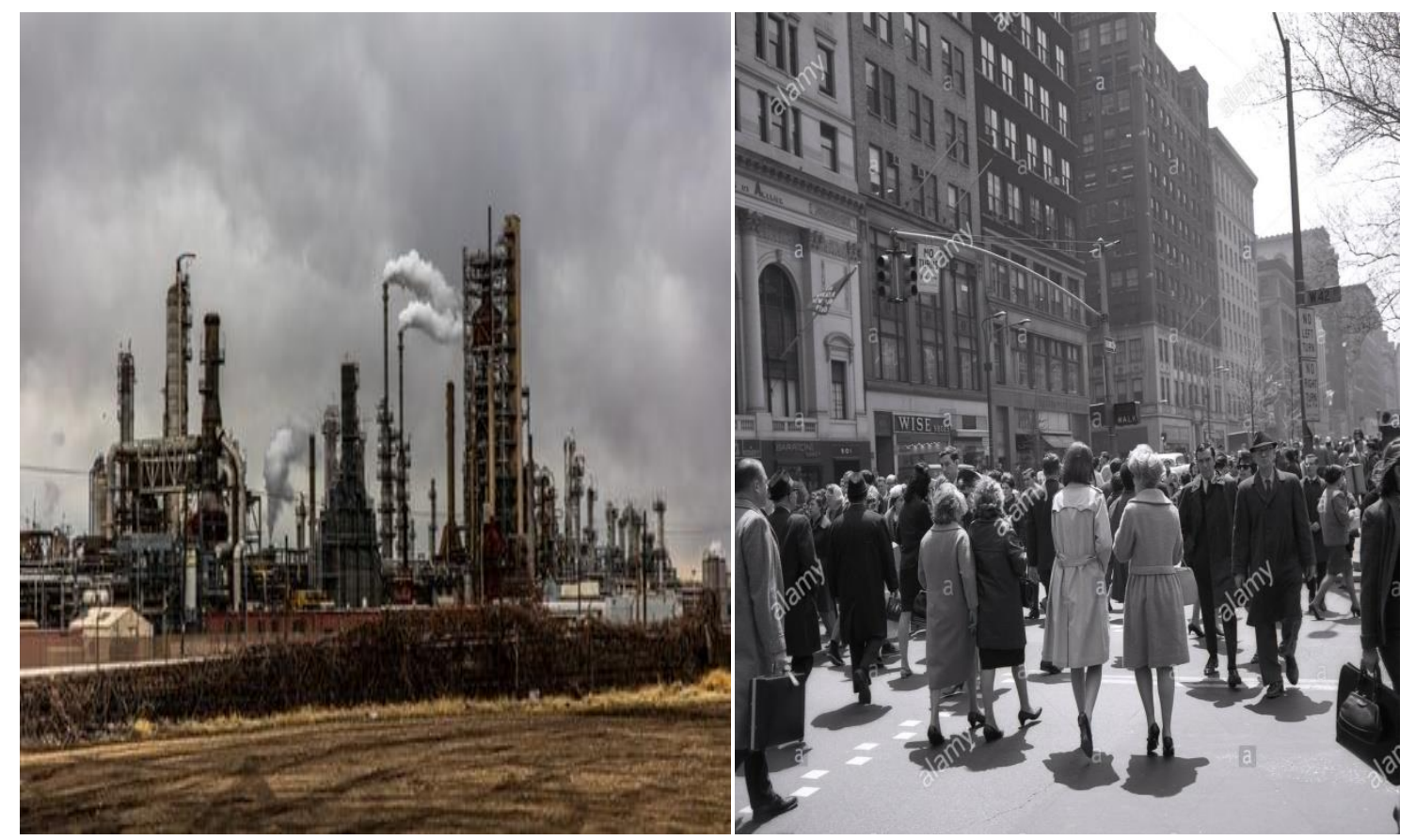

Picture 4. Industries and acculturation without form among national communities in New York 1960s

Source: https://www.history.com accessed on April 21, 2020 at 01.21 p.m. 


\section{Northern region of United States}

The Northern region is a beautiful and comfortable landscape. This area is very good to be a hunting area because it has a diversity of birds and animals. The community generally spends their time as breeders with the main commodities being meat and milk. There are also people who work in the fields of potatoes and tomatoes.

The Northern region is a description of the structure of a new society that is plural and tolerant of various nations, including the people of France, Canada, Philippines, Mexico, Indians, Negroes, and others. They also have different religions, namely Catholicism, Protestantism, Hinduism, and Animism/Dynamism beliefs. These various ethnic and national backgrounds bring together a diversity of customs, traditions, behaviours, myths, and life goals. Although they are diverse, but they are able to build a social life that is organized, peaceful, and harmonious. The social life of people in this area can be said to be the unity in diversity.

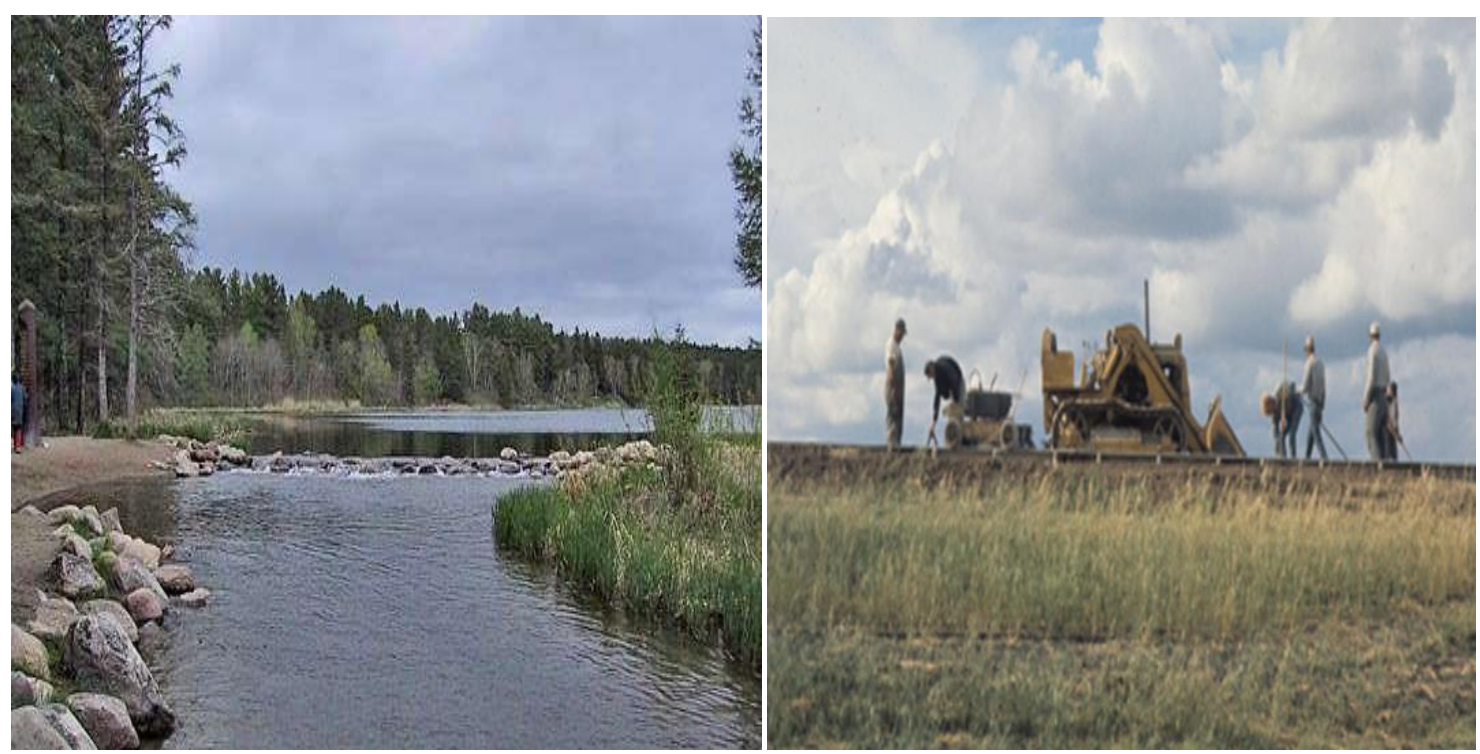

Picture 5. Lake Itasca, Minnesota and Farming activities in North Dakota 1960s Source: https://www.history.com accessed on April 21, 2020 at 01.25 p.m.

\section{Middle region of United States}

Valleys, mountains, streams, and waterfalls are the views that dominate the Middle region of America. In this Middle area, there is a very beautiful waterfall object in Colorado called Niagara Falls. This natural condition is very suitable for agriculture, plantations, and animal husbandry. Many people use their land to grow crops such as wheat, corn, potatoes, tomatoes, pumpkins, and beans. There are also those who breed, sell, miners, and others. 
This area was originally an Indian reservation, but was invaded by frontier people in the mid-nineteenth century. They come looking for new land to settlement and cultivation. They are dominated by immigrant communities from Norway, Ireland, Germany, France, China, Russia, and others. Their relationship with the Indians was not in harmony. The Indians as an indigenous community are pushed and marginalized in remote areas or into the forest. The social description of the people in this area is the frontier community who help each other and try to live in harmony, even though they have different religious backgrounds, nationalities, languages, professions, social status. Their population has increased rapidly. Different language backgrounds make them try to use English as a connecting language.

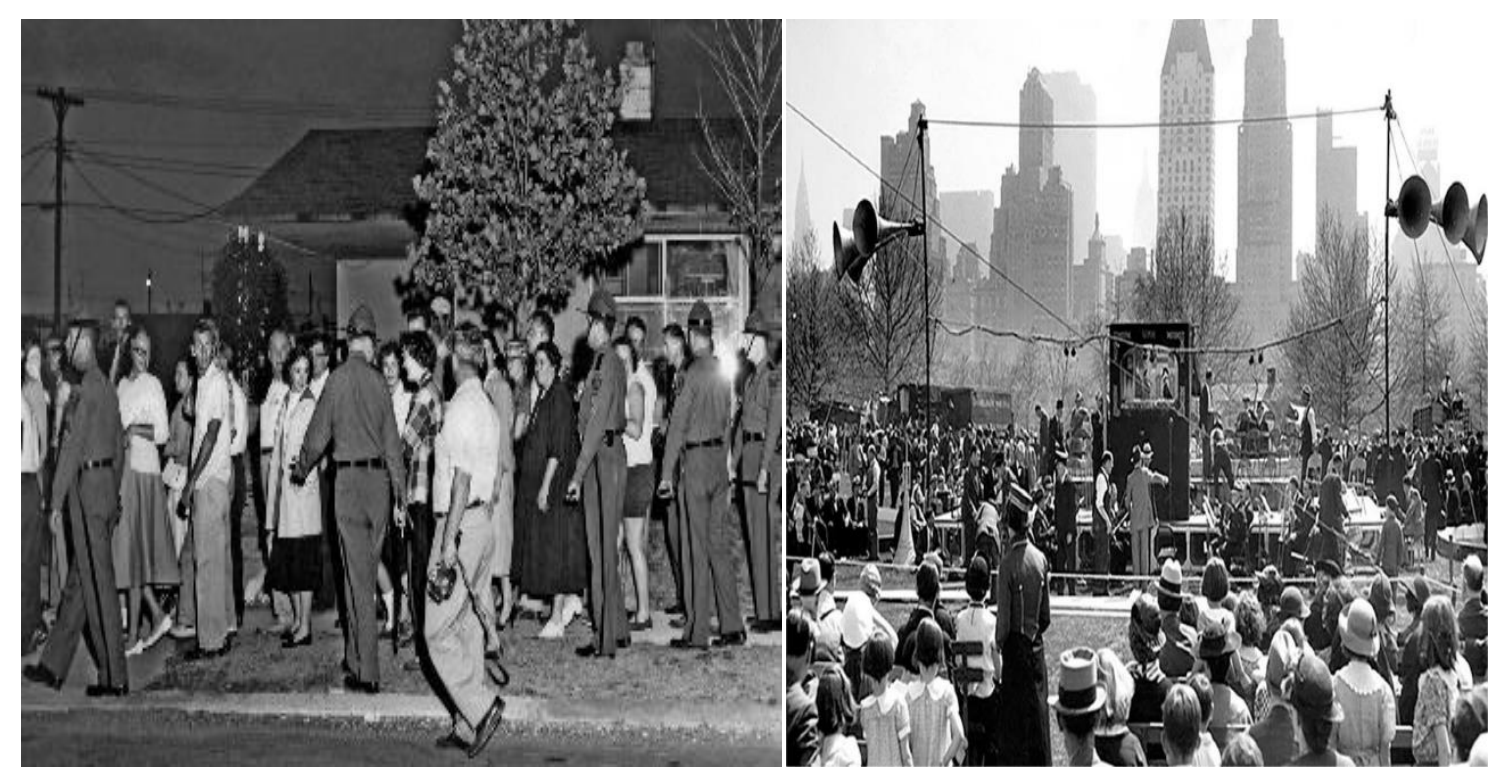

Picture 6. Population has different language backgrounds of Norway, Ireland, Germany, France, China, Russia, and others in Middle Region 1960s Source: https://www.history.com accessed on April 21, 2020 at 01.28 p.m.

\section{Western region of United States}

The Western American region facing the Pacific Ocean is a beautiful stretch of beach with rows of rocks that block the waves. This area also has natural forests that still hold giant trees. Many people become fishermen who use the sea as a place to find fish, shellfish, and pearls.

This region has a unique social description because the Negroes whose ancestors used to be slaves, apparently many are successful in the economic sector. They successfully opened a trading and doing business with French people. Immigrants from East Asia such as Japan and China also inhabited this area and were successful in 
business and commerce. Their population is increasing fast and making several developing cities become crowded. Another reality is the fate of Indians who are not as successful as Negroes and Asian immigrants. Indians continue to fight for a decent life in order to obtain their rights in the economic, educational and health sectors.

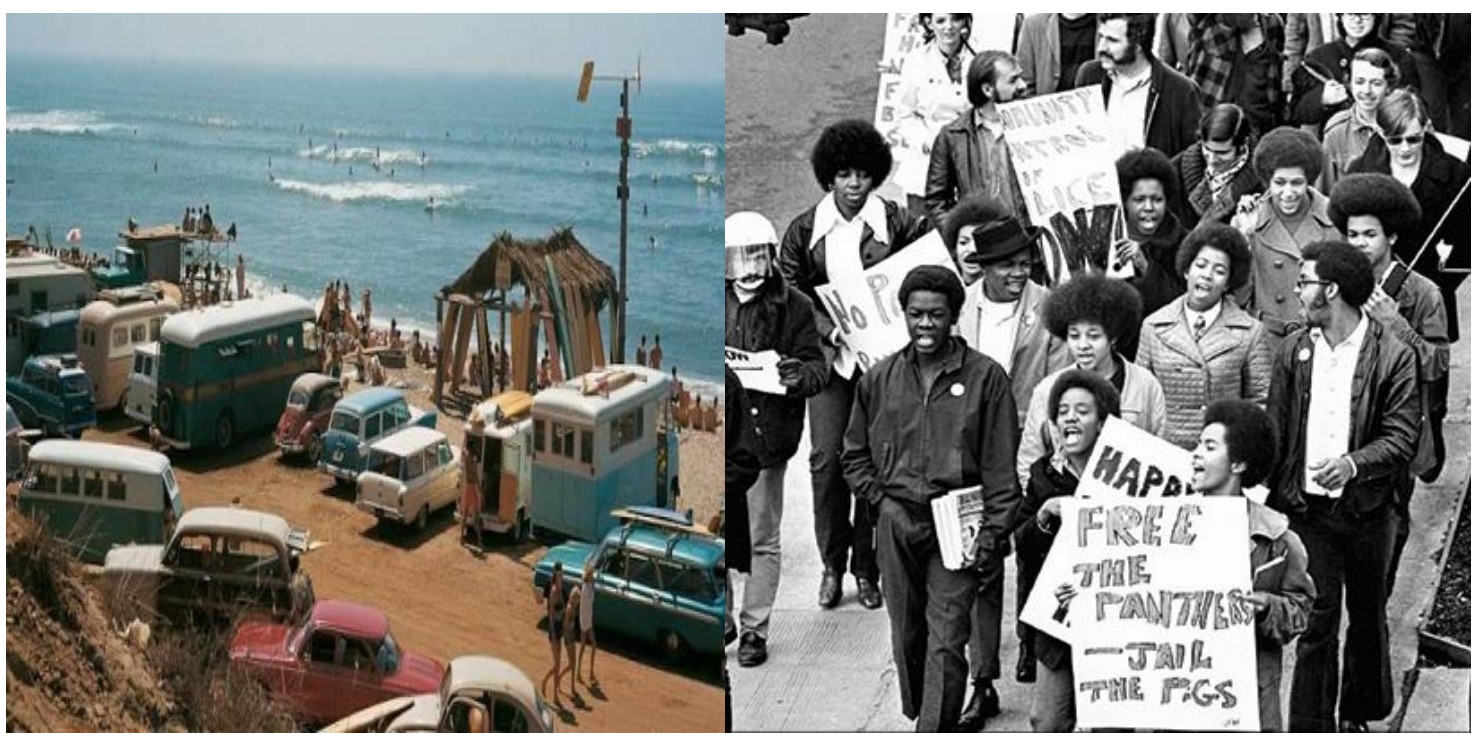

Picture 7. Amazing coast of California facing the Pacific Ocean is a beautiful stretch of beachand Negroes and Asian immigrants were successful in business and commerce in Western Region 1960s Source: https://www.history.com accessed on April 21, 2020 at 01.28 p.m.

\section{Southern region of United States}

Varied natural conditions from the plains and valleys to the hills make the Southern region suitable for plantation land. This area is the entrance to the US border with Latin American countries such as Mexico. Several states such as Texas, New Mexico, and California were previously part of the territory of the State of Mexico which was dominated by Indian culture. In 1845, the United States annexed the territory of Texas and its surroundings which resulted in a two-year war from April 1846 to February 1848. The war ended with the transfer of Texas, New Mexico, and California to the United States and Mexico recognized the Rio Grande as a state border with the United States. In the Treaty of Guadalupe Hidalgo in 1848, the United States also paid compensation for infrastructure damage to Mexico of $\$ 15$ million.

The people of the Southern region in the past were plantation landowners who employed Negroes as slaves. Extreme natural conditions make the people in this region become hard, firm, and disciplined. The social description of this region is a society full of terror and prone to violence. However, they are unique because they have high 
solidarity. They have a strong unity when facing challenges from outside. Their fellow conflicts are common, but they immediately come together to face the threat of outsiders as a common enemy. The characters of the people are friendly and helpful, but wary of the influence of outsiders.

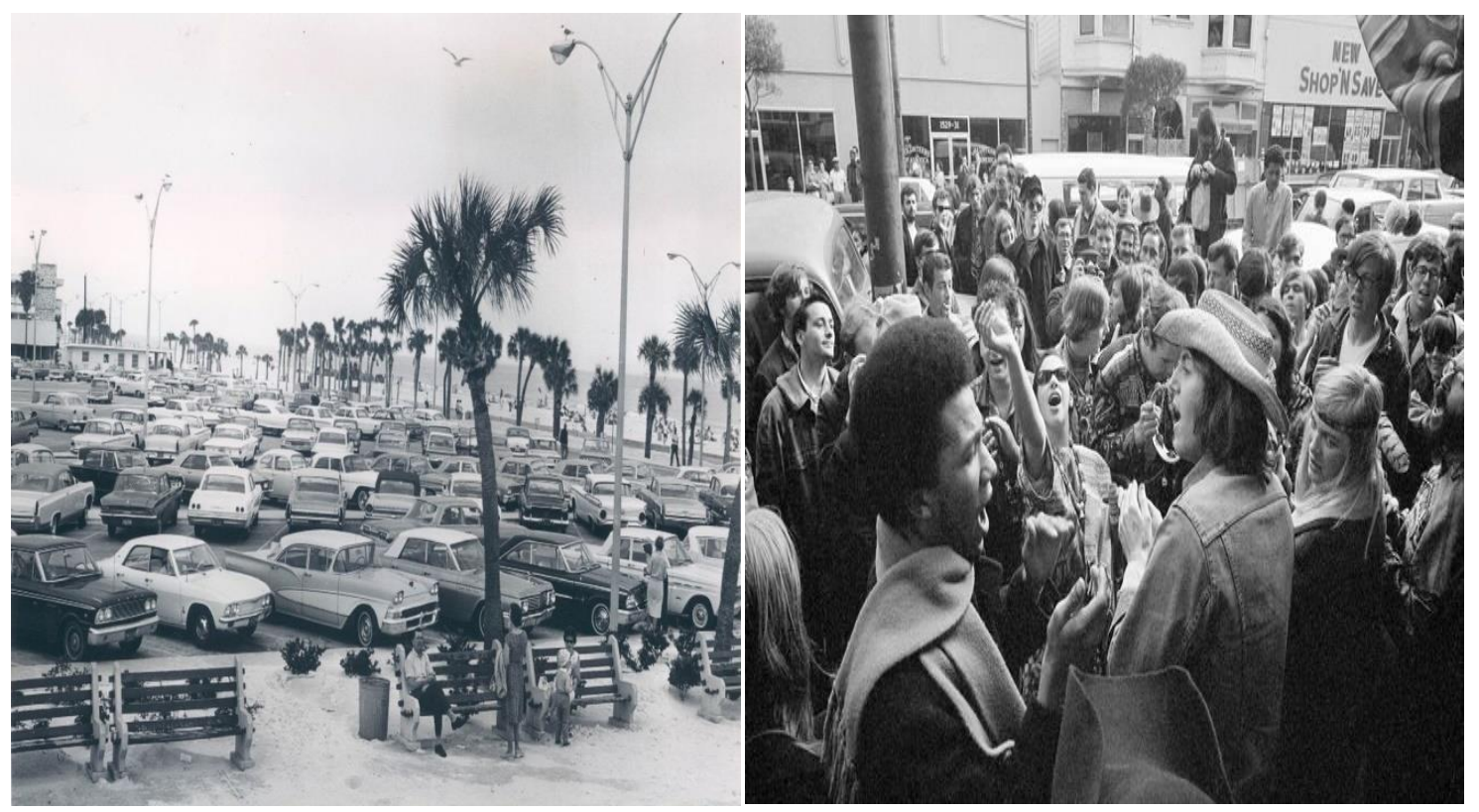

Picture 8. Beach, Florida and Societies have a high solidarity of facing challenges from outside as a common enemy in Southern Region 1960s

Source: https://www.history.com accessed on April 21, 2020 at 01.30 p.m.

\section{CONCLUSION AND SUGGESTION}

\section{Conclusion}

The exploration of the American nation through literary studies shows that John Steinbeck as the author of the novel Travels with Charley in Search of America has a subjective involvement in his work. This research is able to prove the author's subjective involvement in his fictional works by opening up structural spaces in literary works as the basic principles developed in the Dynamic Structural Approach. This approach is a literary study method that involves the author in tracing the orientation of a fictional story so the character of the story are no longer seen as an autonomous figure, but he carries the mission of the author.

Novel Travels with Charley in Search of America is a work of fiction that documents America's social and geographical conditions as a unique nation. John Steinbeck as the author describes the diversity of nations, languages, cultures, races, ethnicities, skin colors, religions, ideas, and ideals which gather in a region of nation 
and country called America. He explored his country to find his national identity. America cannot be defined only by one particular region, but this country is a whole community with diversity in it. He is a nationalist-minded writer who is critical and sensitive to his country America. The American identity is a country of various nations in the world. The diversity of backgrounds in social life, that is actually the nation of America. They come from different backgrounds, but their souls are one in America. American democracy grows from this diversity and unity in difference can only be maintained by prosperity and justice. To know the identity of America must go through knowledge of America from all corners of the region, from East, North, Middle, West to South. America's geographical situation stretching from valleys to mountains, from rivers to lakes, and from oceans to oceans, is an extraordinary natural wealth with amazing views. They are unity in diversity.

\section{Suggestion}

John Steinbeck was a realist author who criticized the conditions of American society in the early and mid-twentieth century. It means that the literary works that he produces having a documentation of the conditions of American society which are imagined with typical rural communities. The writer thinks about comparing the reality of rural society in some of John Steinbeck's works with the reality of urban society from the literary works of other American authors such as Francis Scott Fitzgerald. Thus, the writer suggests other literary researchers to make a comparative study of American social conditions as a reflection of a number of literary works.

\section{REFERENCES}

Abbas. (2020). The Reality of American Nation Slavery in the Novel Incidents in the Life of a Slave Girl by Harriet Ann Jacobs. https://www. Journal.unhas.ac.id /index.php/jib. Accessed on November 11, 2020 at 09.48 p.m.

Alwi. (2019). “Racism in Twain's The Adventures of Huckleberry Finn”. Thesis of Undergraduate. Makassar: Departemen Sastra Inggris FIB Universitas Hasanuddin.

DeMOTT, Robert \& Brian R. (2007). Prospects for the Study of John Steinbeck. https://www.jstor.org/stable/26367107?seq=1. Accessed on November 10, 2020 at 09.48 p.m.

Edy, Ariska, Hasyim M., \& Astuti M.S.P. (2020). The Comparison of Visual Appearance between Sawerigading and Hikaru Genji: Symbolism of the 
Buginese-Japanese Masculinity in Folklore Reconstruction. Proceeding BASA Surakarta Indonesia, 21-22 September 2019.

Endraswara, S. (2013). Metodologi Penelitian Sastra: Epistemologi, Model, Teori, dan Aplikasi. Jakarta: Center for Academic Publishing Services (CAPS).

Faruk. (2014). Pengantar Sosiologi Sastra, dari Strukturaisme Genetik sampai Postmodernisme. Yogyakarta: Pustaka Pelajar.

Goring, P., et al. (2001). Studying Literature: The Essential Companion. USA: Oxford University Press.

Hart, J. D. (1986). The Concise Oxford Companion to American Literature. New York: Oxford University Press.

Mas'ud, B. (2013). “Moral Values in Hemingway's The Old Man and the Sea in the Education of Character Building". Thesis of Undergraduate. Makassar: Departemen Sastra Inggris FIB Universitas Hasanuddin.

Olson, K. W. (1992). An Outline of American History. USA: University of Maryland.

Pearson, M. (1994). Tempat-Tempat Imajiner. Perlawatan ke Dunia Sastra Amerika. Translated by Sori Siregar, et al. Jakarta: Yayasan Obor Indonesia.

Rakshna. (2016). A Short Article on Adventure. https://brainly.in/question/377394. Accessed on November 11, 2020 at 09.15 p.m.

Ratna, N. K. (2015). Teori, Metode, dan Teknik Penelitian Sastra. Yogyakarta: Pustaka Pelajar.

Steinbeck, J. (1986). Travels with Charley in Search of America. USA: Penguin Book. 